\title{
Optimalisasi Beaufort Cipher Menggunakan Pembangkit Kunci RC4 Dalam Penyandian SMS
}

\author{
Mia Diana ${ }^{1}$, Taronisokhi Zebua ${ }^{2}$ \\ ${ }^{1}$ Prorgram Studi Teknik Informatika STMIK Budidarma Medan \\ ${ }^{2}$ Program Studi Teknik Informatika AMIK STIEKOM Sumatera Utara \\ ${ }^{1}$ Jl. SM. Raja No. 338 Sp. Limun Medan \\ ${ }^{2}$ Jl. H. Adam Malik No. 18 Rantauparapat, Labuhan Batu, Sumatera Utara \\ ${ }^{1}$ miadiana@gmail.com, ${ }^{2}$ taronizeb@gmail.com
}

\begin{abstract}
The key in the cryptography algorithm is a very important role in the process of encryption and decryption. The more random key numbers are used, the more random the ciphers are generated. The RC4 algorithm and the Beaufort cipher are algorithms of cryptographic techniques. The RC4 algorithm has advantages in generating random keys, whereas Beaufort ciphers have a disadvantage in terms of the number of keys used too much. This research describes how to optimize key formation in Beaufort algorithm by utilizing the key generation process on the RC4 algorithm which is implemented on encoding SMS which until now has not been point-to-point (not directly sent to destination). The results of this study provide convenience for users in the process of generating encryption and decryption keys and generate SMS cipher more random and difficult to understand by others.
\end{abstract}

Keywords : SMS, Cryptography, Stream Cipher, RC4, Beaufort Cipher

\begin{abstract}
Abstrak
Kunci pada algoritma kriptografi sangat penting peranannya dalam proses enkripsi dan dekripsi. Semakin acak bilangan kunci yang digunakan, maka semakin acak pula cipher yang dihasilkan. Algoritma RC4 dan beaufort cipher merupakan algoritma dari teknik kriptografi. Algoritma RC4 memiliki kelebihan dalam membangkitkan kunci yang acak, sedangkan beaufort cipher memiliki kelemahan dalam hal jumlah kunci yang digunakan terlalu banyak. Penelitian ini menguraikan bagaimana mengoptimalkan pembentukan kunci pada algoritma beaufort dengan memanfaatkan proses pembangkitan kunci pada algoritma RC4 yang diimplementasikan pada menyandikan SMS yang sampai saat ini belum bersifat point-to-point (tidak langsung dikirim kepada tujuan). Hasil penelitian ini memberikan kemudahan bagi pengguna dalam proses pembangkitan kunci enkripsi maupun dekripsi serta menghasilkan cipher SMS yang lebih acak dan sulit dipahami oleh pihak lain.
\end{abstract}

Kata Kunci: SMS, Kriptografi, Cipher Aliran, RC4, Beaufort Chiper

\section{PENDAHULUAN}

Kriptografi merupakan salah satu teknik yang dapat digunakan dalam mengamankan data yang bersifat rahasia atau pribadi. Proses transformasi informasi yang berlangsung dua arah yang terdiri dari proses enkripsi dan dekripsi adalah ruanglingkup dari kriptografi[1]. Saat ini pemanfaatan teknik kriptografi pada bidang komunikasi sangat berkembang. Berdasarkan penelitian sebelumnya yang dilakukan oleh Setyaningsih mengatakan bahwa teknik kriptografi sangat penting diimplementasikan untuk melindungi data yang 
ditransmisikan melalui suatu jaringan komunikasi[2]. Algoritma RC4 dan beaufort cipher merupakan contoh dari algoritma kriptografi.

Peranan kunci pada algoritma kriptografi sangat penting dalam melakukan proses enkripsi dan dekripsi data. Bilangan kunci yang acak akan menghasilkan cipher yang acak pula sehingga dapat menambah kerumitan bagi penyerang untuk memecahkan algoritma yang digunakan. Keamanan suatu pesan tidak tergantung pada algoritma yang digunakan dalam menyandikannya, namun tergantung pada kunci yang digunakan tanpa mengandung pola dan harus acak[1][2]. Oleh karena itu, maka pemlihan dan pemrosesan pembangkitan kunci dalam proses enkripsi dan dekripsi harus lebih baik.

Algoritma RC4 membangkitkan deretan kunci yang sangat acak, sehingga sangat sulit dipecahkan oleh pihak lain[3][4]. Beaufort cipher merupakan salah satu dari jenis kriptografi klasik dan merupakan varian algoritma vigeneere cipher. Beaufort cipher menggunakan kunci yang jumlah sama dengan jumlah plain[1]. Artinya bahwa bila pengguna memiliki panjang plaintext 200 karakter, berarti kunci yang digunakan harus 200 karakter. Hal inilah yang menjadi salah satu kelemahan dari algoritma beaufort cipher, karena akan sangat sulit bagi pengguna untuk menghafal kunci dengan panjang yang sama seperti plaintext.

Short Message Service (SMS) merupakan salah satu fasilitas yang disediakan oleh ponsel dan berfungsi sebagai salah satu media untuk berkomunikasi khususnya untuk melakukan pengiriman dan penerimaan data berupa pesan singkat. Hingga saat ini, pemanfaatan layanan ini sudah sangat berkembang di kalangan masyarakat. Namun layanan komunikasi dengan media SMS saat ini masih harus melewati pusat penyedia layanan dan belum bersifat point-to-point, sehingga hal ini dapat memungkinkan terjadinya penyadapan SMS yang sedang berada dalam proses distribusi[5]. Penelitian yang dilakukan oleh Purwaningsih mengatakan bahwa komunikasi via SMS memiliki celah keamanan terbesar dimana pesan yang dikirimkan akan disimpan di SMSC (Short Message Service Center) sebelum dikirim ke tujuan[6]. Tentu hal ini akan lebih berdampak negatif bila informasi atau pesan yang didistribusikan melalui SMS adalah pesan rahasia atau penting.

Penelitian ini menguraikan bagaimana mengoptimalkan proses pembangkitan kunci pada beaufort cipher dengan memanfaatkan proses pembangkitan kunci pada algoritma RC4 yang diimplementasikan pada penyandian teks SMS. Kunci yang dihasilkan akan dimanfaatkan sebagai kunci dalam proses enkripsi dan dekripsi teks SMS berdasarkan beaufort cipher, sehingga diperoleh cipher SMS yang lebih acak tidak lagi mudah dipahami.

\section{METODOLOGI PENELITIAN}

\subsection{Short Message Service (SMS)}

Fitur Short Message Service (SMS) merupakan salah satu aplikasi yang dikembangkan dan disediakan pada handphone sebagai salah satu fasilitas untuk bertukar pesan atau informasi[6]. Salah satu faktor perkembangan penggunaan SMS ini sebagai media berkomunikasi adalah layanan kemudahan serta biaya pengiriman SMS yang relatif murah. SMS yang dikirimkan melalui layanan SMS saat ini tidak langsung dikirimkan kepada penerima yang dituju, namun harus 
melewati Short Message Service Center (SMSC) yang bertugas untuk mencatat komunikasi yang terjadi antara pengirim dan penerima[7]. Setelah SMS tercatat pada SMSC, barulah SMS tersebut diteruskan kepada penerima yang dituju.

\subsection{Kriptografi}

Kriptografi merupakan studi terhadap teknik matematis yang terkait dengan aspek keamanan suatu sistem informasi seperti kerahasiaan, integritas data, autentikasi dan ketiadaan penyangkalan[8]. Teknik kriptografi memiliki berbagai algoritma yang digunakan dalam mengamankan data, misalnya Caesar Cipher, Vigeneere Cipher, Affine Cipher, DES, RC4, RC6, AES, GOST, dan lain-lain. Hal yang harus dicapai dalam penerapan algoritma kriptografi adalah confusion (konfusi/pembingungan) yaitu harus mampu mempersulit pihak lain dalam merekonstruksi ulang cipher yang dihasilkan serta diffusion (peleburan) yaitu harus mampu menyembunyikan pola dari pesan asli[9].

Pengamanan data berdasarkan algoritma teknik kriptografi dilakukan dengan merubah pesan yang akan dirahasiakan plaintext menjadi sandi (ciphertext). Proses untuk mengkonversi plaintext menjadi ciphertext disebut dengan proses enkripsi sedangkan proses yang dilakukan untuk mengembalikan ciphertext menjadi plaintext disebut deskripsi[8][10]. Proses enkripsi dan dekripsi memerlukan sebuah kode dalam pelaksanaannya yang disebut dengan kunci. Kunci harus harus bersifat rahasia dan tidak boleh diberitahukan kepada orang lain yang tidak berhak untuk menerima pesan.

\subsection{Algoritma RC4}

Algoritma RC4 ditemukan pada tahun 1978 oleh Ronald Rivest dan merupakan pengembangan dari algoritma RC sebelumnya. Panjang kunci yang digunakan oleh RC4 adalah 1 byte hingga 256 byte dan digunakan untuk menginisialisasikan tabel sepanjang 256 byte[5]. Sebagai stream cipher (cipher aliran), maka algoritma RC4 melakukan proses enkripsi dan dekripsi secara satu persatu berdasarkan kunci yang telah dibangkitkan sebelumnya. Ada tiga proses utama pada algoritma RC4, yaitu proses Key Schedulling Algorithm (KSA), Pseudo Random Generation Algorithm (PRGA) dan proses enkripsi maupun dekripsi[3]. Kunci yang dibangkitkan berdasarkan algoritma RC4 sangat acak, namun kelemahan algoritma ini adalah mudahnya diserang oleh para kriptanalis dengan jenis know-plain attack maupun cipher-only attack [2][3] karena proses enkripsi dan dekripsinya yang sanngat sederhana.

\subsubsection{Key Schedulling Algorithm (KSA)}

Proses penjadwalan kunci (key Schedulling) dilakukan dengan tujuan membangkitkan kunci yang acak sejumlah 256 buah kunci. Penjadwalan kunci melibatkan dua tabel array yaitu array S dan array T. Proses pengacakan dilakukan dengan menukarkan nilai-nilai array S yang sebelumnya dikalkulasikan dengan nilai-nilai array T. Adapun pseudocode untuk melakukan pembentukan array $\mathrm{S}$ dan T adalah :

$$
\begin{aligned}
& \text { for }(\mathrm{i}=0 ; \mathrm{i}<=255 ; \mathrm{i}++)\{ \\
& \quad \text { S-Box }[\mathrm{i}]=\mathrm{i}
\end{aligned}
$$




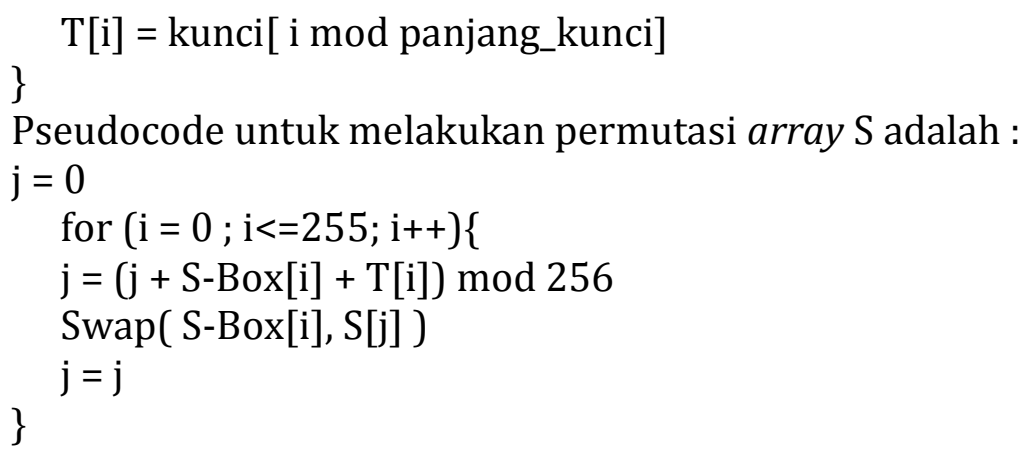

\subsubsection{Pseudo Random generation Algorithm (PRGA)}

Proses pseudo random generation merupakan proses yang dilakukan untuk membangkitkan kunci sebanyak elemen plaintext yang akan dienkripsi. Proses ini melibatkan nilai-nilai pada tabel array $\mathrm{S}$ yang telah dipermutasi (diacak). Kuncikunci inilah nantinya yang akan di XOR-kan dengan plaintext. Adapun pseudo code untuk melakukan PRGA adalah :

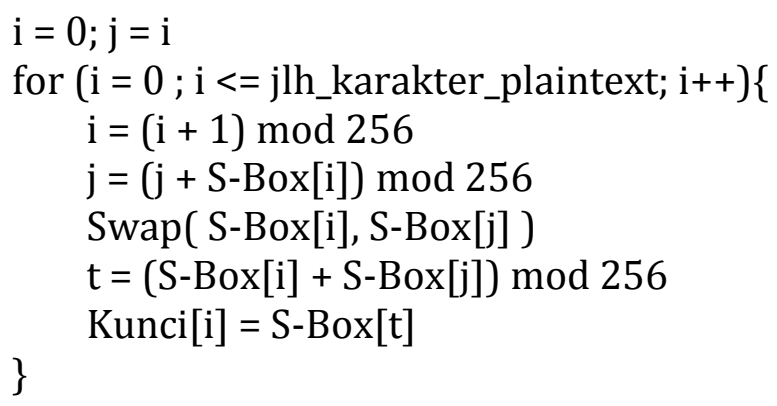

\subsubsection{Enkripsi dan Dekripsi}

Proses enkripsi dan dekripsi dilakukan dengan cara yang sederhana yaitu melakukan proses XOR antara biner plaintext dengan biner kunci yang telah dibangkitkan dari proses PRGA.

Formula enkripsi adalah :

$\mathrm{Ci}=\mathrm{Pi} \oplus \mathrm{Ki}$

Formula dekripsi adalah :

$\mathrm{Pi}=\mathrm{Ci} \oplus \mathrm{Ki}$

\subsection{Beaufort Cipher}

Beaufort cipher merupakan salah satu algoritma dalam teknik keamanan kriptografi klasik. Kunci (K) pada beaufort cipher adalah urutan karakter-karakter $K=k_{1} \ldots k_{\mathrm{d}}$ dimana $k_{1}$ didapat dari banyaknya pergeseran dari alfabet ke- $i$ sama seperti viginere cipher[1]. Artinya bahwa jumlah kunci yang dibangkitkan harus sama dengan jumlah karakter plaintext yang diamankan. Algoritma ini melakukan proses enkripsi dan dekripsi secara stream (masing-masing karakter plaintext harus memiliki pasangan kunci). Hal ini yang menyebabkan algoritma ini sama hampir sama dengan algoritma vigeneere cipher. Adapun formulasi yang digunakan dalam proses enkripsi dan dekripsi [2][11] adalah :

Formula proses enkripsi :

$\mathrm{C}_{\mathrm{i}}=\mathrm{E}_{\mathrm{k}}\left(\mathrm{M}_{\mathrm{i}}\right)=\left(\mathrm{K}_{\mathrm{i}}-\mathrm{M}_{\mathrm{i}}\right) \operatorname{Mod} 26$ 
Formula proses dekripsi :

$\mathrm{M}_{\mathrm{i}}=\mathrm{D}_{\mathrm{k}}\left(\mathrm{C}_{\mathrm{i}}\right)=\left(\mathrm{K}_{\mathrm{i}}-\mathrm{C}_{\mathrm{i}}\right) \operatorname{Mod} 26$

Keterangan :

$\mathrm{Mi}=$ Pesan yang akan dienkripsi (plain)

$\mathrm{Ci}=$ Sandi (cipher) $\mathrm{Ki}=$ Kunci

Ek $=$ Fungsi Enkripsi $\quad$ Dk $\quad=\quad$ Fungsi Dekripsi

Nilai mod 26 di atas tergantung dari jumlah kebutuhan karakter yang digunakan, pada awalnya beaufort cipher hanya menggunakan 26 karakter, namun seiring dengan perkembangan teknologi komputer saat ini, maka dapat menggunakan mod 256 (mengguakan seluruh tabel ASCII).

\section{HASIL DAN PEMBAHASAN}

\subsection{Analisa Masalah}

Proses penentuan kunci dalam enkripsi dan dekripsi data berdasarkan beaufort cipher sangat sederhana, namun jumlah kunci yang digunakan menjadi salah satu hal yang menyita waktu banyak bagi pengguna. Berdasarkan teoritis bahwa jumlah kunci yang digunakan pada beaufort cipher berbanding lurus (sama dengan) jumlah karakter plaintext, menyebabkan pengguna kesulitan mengingat kata kunci yang digunakan pada proses enkripsi maupun dekripsi. Umumnya hal ini dapat diatasi dengan melakukan pengulangan kunci yang jumlahnya lebih sedikit hingga jumlanya sama dengan banyaknya plaintext. Namun hal ini tidaklah memenuhi kaidah kunci kriptografi yang baik.

Proses pembangkitan kunci berdasarkan algoritma RC4 mampu menghasilkan bilangan-bilangan kunci yang acak sejumlah plaintext. Artinya proses key schedulling dan pseudo random generation akan membangkitkan kunci yang baru dengan jumlah yang sama seperti jumlah plaintext. Pemanfaatan kunci yang dibangkitkan berdasarkan algoritma RC4 sebagai kunci dalam proses enkripsi maupun dekripsi berdasarkan beaufort cipher tentu akan mengoptimalkan ketahanan dan memudahkan proses pembangkitan kunci pada cipher ini khususnya untuk menyandikan SMS.

Adapun skema optimasi yang dilakukan pada beaufort cipher dalam menyandikan SMS ditunjukkan pada gambar 1.

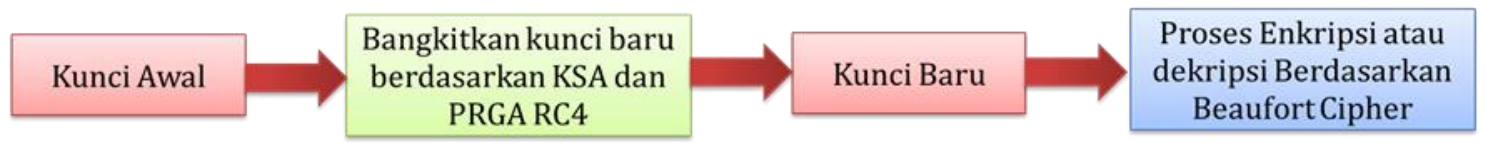

\section{Gambar 1. Skema Otimalisasi Pembangkitan Kunci pada Beaufort Cipher}

Berdasarkan gambar 1 di atas, terlihat bahwa kunci yang digunakan pada proses enkripsi maupun dekripsi bukan lagi kunci yang diberikan pada awal, melainkan akan dibangkitkan kunci-kunci yang baru yang lebih acak dan berbeda dengan kunci awal. Kelebihan teknik ini adalah pengguna tidak lagi harus menginputkan kunci sejumlah plaintext. pengguna dapat saja menginpukan jumlah kunci yang jauh lebih kecil dari jumlah plaintext karena secara otomatis akan dibangkitkan kunci-kunci baru sejumlah plaintext berdasarkan proses key schedulling dan pseudo random generation berdasarkan algoritma RC4. Kunci baru 
yang dihasilkan pada proses inilah yang digunakan untuk melakukan enkripsi dan dekripsi SMS berdasarkan algoritma beaufort cipher.

Skema penerapan algoritma beaufort cipher yang telah teroptimalisasi dalam penyandian SMS ditunjukkan pada gambar di bawah ini :

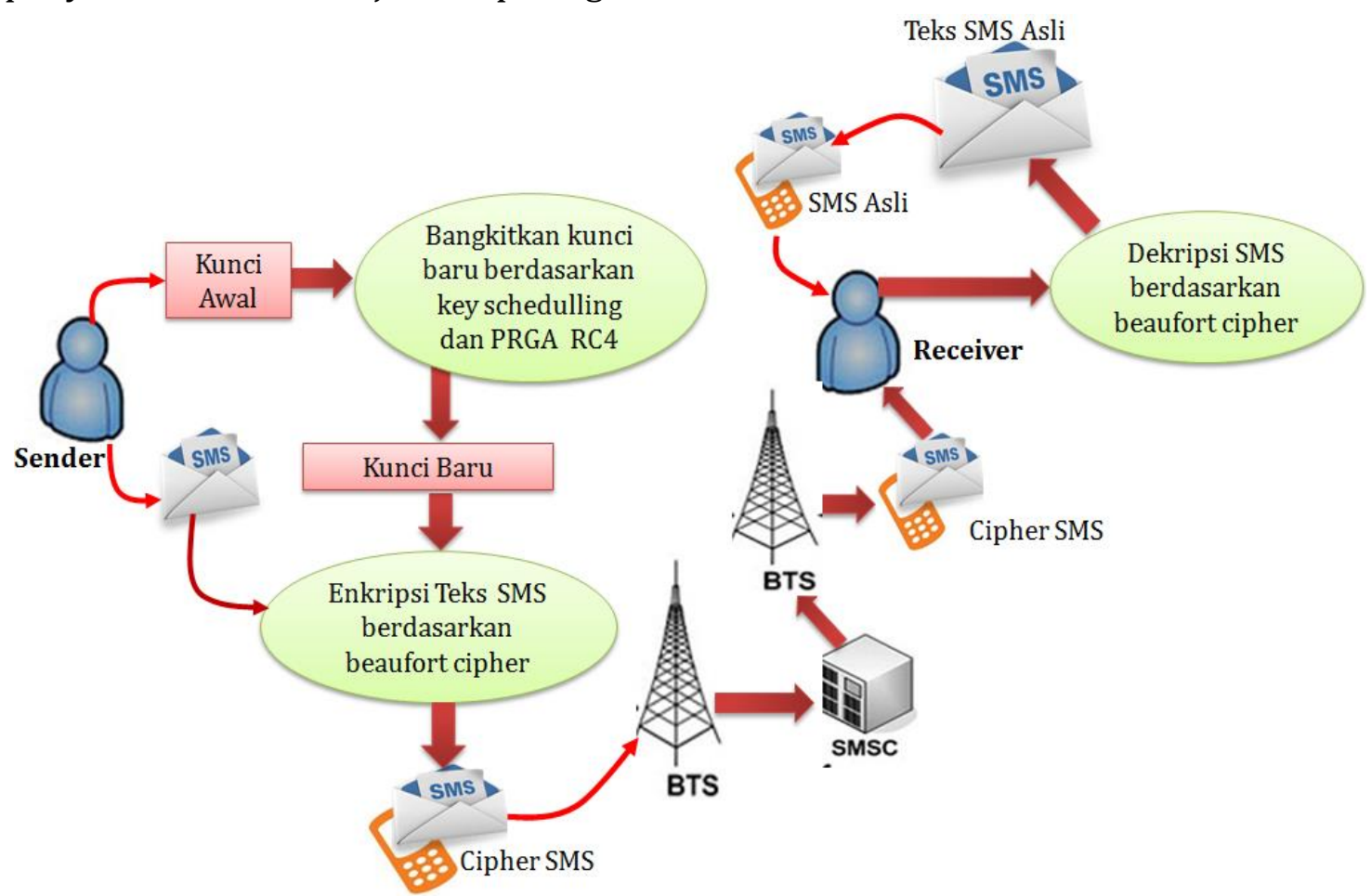

\section{Gambar 2. Skema Implementasi Penyandian SMS Berdasarkan Beaufort Cipher yang telah dioptimalisasikan}

Berdasarkan gambar 2 di atas, terlihat bahwa SMS yang dikirim melalui handphone pengirim kepada penerima adalah SMS yang telah disandikan terlebih dahulu berdasarkan beaufort cipher yang telah dioptimalisasikan proses pembentukan kunci yang digunakan. Walaupun proses pengiriman SMS belum bersifat point-to-point, maka SMS tersebut tetap tidak dapat dipahami oleh pihak lain yang berhasil menyadapnya.

Proses pengamanan ini dilakukan dengan membangun aplikasi pengiriman SMS pada handphon yang dilengkapi dengan fitur enkripsi dan dekripsi SMS. Proses penyandian SMS dilakukan oleh penerima berdasarkan algoritma yang sama dan kunci yang sama. Oleh karenanya sebelum kedua belah pihak melakukan distribusi SMS, maka kedua belah pihak harus telah menyepakati kunci yang digunakan.

\subsection{Implementasi}

Contoh kasus berikut ini akan mengimplementasikan pembangkitan kunci beaufort cipher berdasarkan proses key schedulling algorithm dan pseudo random generation algorithm pada algoritma RC4. Asumsikan teks SMS yang dijadikan sebagai plaintext adalah Hai Mia... Kemudian ditetapkan kunci awal adalah Diana. 
Berdasarkan skema optimalisasi pembentukan kunci (gambar 1) terhadap beaufort cipher, maka sebelum proses enkripsi dan dekripsi dilakukan terlebih dahulu dilakukan proses KSA dan PRGA berdasarkan algoritma RC4.

1. Proses Key Schedulling Algorithm (KSA)

Teks SMS = Hai Mia...

Kunci Awal = Diana

Sebelum dilanjutkan pada proses selanjutnya, maka terlebih dibuat tabel array untuk kunci awal.

Tabel 1. Tabel Array Kunci Awal

\begin{tabular}{ccc}
\hline Index & Char Kunci & Nilai ASCII \\
\hline 0 & $\mathrm{D}$ & 68 \\
1 & $\mathrm{i}$ & 105 \\
2 & $\mathrm{a}$ & 97 \\
3 & $\mathrm{n}$ & 110 \\
4 & $\mathrm{a}$ & 97 \\
\hline
\end{tabular}

Proses pembentukan array S, yaitu tabel berisi array dengan jumlah 255 dan isi array dimulai dari 0-255. Proses ini dilakukan berdasarkan pseudocode KSA, sehingga dihasilkan array $\mathrm{S}$ sebagai berikut :

Tabel 2. Nilai Array $S$

\begin{tabular}{llllllllllllllll}
\hline 0 & 1 & 2 & 3 & 4 & 5 & 6 & 7 & 8 & 9 & 10 & 11 & 12 & 13 & 14 & 15 \\
16 & 17 & 18 & 19 & 20 & 21 & 22 & 23 & 24 & 25 & 26 & 27 & 28 & 29 & 30 & 31 \\
32 & 33 & 34 & 35 & 36 & 37 & 38 & 39 & 40 & 41 & 42 & 43 & 44 & 45 & 46 & 47 \\
48 & 49 & 50 & 51 & 52 & 53 & 54 & 55 & 56 & 57 & 58 & 59 & 60 & 61 & 62 & 63 \\
$\vdots$ & $\vdots$ & $\vdots$ & $\vdots$ & $\vdots$ & $\vdots$ & $\vdots$ & $\vdots$ & $\vdots$ & $\vdots$ & $\vdots$ & $\vdots$ & $\vdots$ & $\vdots$ & $\vdots$ & $\vdots$ \\
224 & 225 & 226 & 227 & 228 & 229 & 230 & 231 & 232 & 233 & 234 & 235 & 236 & 237 & 238 & 239 \\
240 & 241 & 242 & 243 & 244 & 245 & 246 & 247 & 248 & 249 & 250 & 251 & 252 & 253 & 254 & 255 \\
\hline
\end{tabular}

Setiap kolom diberi index dari kiri ke kanan dengan index yang dimulai dari 0 hingga 255. Kolom pertama baris pertama berarti index 0 nilainya 0 , kolom kedua baris pertama adalah index 1 dengan nilai 1, demikian seterusnya.

Langkah selanjutnya adalah membentuk tabel array T. Array T terdiri dari 256 array yang terdiri dari index 0 hingga 255. Nilai array diambil dari nilai-nilai desimal kunci awal berdasarkan pseudocode pembangkitan array T. Proses ini melibatkan nilai-nilai pada tabel 1.

Iterasi $\mathrm{i}=0$, maka :

$\mathrm{T}[0]=$ Kunci $[0 \bmod 5]$

Artinya bahwa isi array T pada index 0 adalah nilai array kunci pada index 0 mod 5. Nilai 5 adalah jumlah karakter (panjang) kunci awal.

Sehingga didapatkan :

$\mathrm{T}[0]=\operatorname{Kunci}[0]=68$, artinya ambil nilai $\operatorname{array} \mathrm{T}$ pada index ke-0 dan jadikan menjadi isi array $\mathrm{T}$ pada index ke-0.

Untuk iterasi $\mathrm{i}=1$, maka :

$\mathrm{T}[1]=$ Kunci[1 $\bmod 5]$

$\mathrm{T}[1]=$ Kunci $[1]=105$ 
artinya ambil nilai array kunci awal pada index ke-1 dan jadikan menjadi isi array $\mathrm{T}$ pada index ke-1.

Proses ini dilakukan hingga iterasi ke 255, sehingga dihasilkan susunan array $\mathrm{T}$ sebagai berikut :

Tabel 3. Nilai Array T

\begin{tabular}{cccccccccccccccc}
\hline 68 & 105 & 97 & 110 & 97 & 68 & 105 & 97 & 110 & 97 & 68 & 105 & 97 & 110 & 97 & 68 \\
105 & 97 & 110 & 97 & 68 & 105 & 97 & 110 & 97 & 68 & 105 & 97 & 110 & 97 & 68 & 105 \\
97 & 110 & 97 & 68 & 105 & 97 & 110 & 97 & 68 & 105 & 97 & 110 & 97 & 68 & 105 & 97 \\
110 & 97 & 68 & 105 & 97 & 110 & 97 & 68 & 105 & 97 & 110 & 97 & 68 & 105 & 97 & 110 \\
$\vdots$ & $\vdots$ & $\vdots$ & $\vdots$ & $\vdots$ & $\vdots$ & $\vdots$ & $\vdots$ & $\vdots$ & $\vdots$ & $\vdots$ & $\vdots$ & $\vdots$ & $\vdots$ & $\vdots$ & $\vdots$ \\
110 & 97 & 68 & 105 & 97 & 110 & 97 & 68 & 105 & 97 & 110 & 97 & 68 & 105 & 97 & 110 \\
97 & 68 & 105 & 97 & 110 & 97 & 68 & 105 & 97 & 110 & 97 & 68 & 105 & 97 & 110 & 97 \\
\hline
\end{tabular}

Langkah berikutnya adalah proses permutasi (pertukaran) nilai-nilai array $\mathrm{S}$ serta pembentukan tabel array $\mathrm{T}$ sebagai acuan untuk membangkitkan kunci yang baru.

Iterasi $\mathrm{i}=0 ; \mathrm{j}=0$

$\mathrm{j}=(0+\mathrm{S}[0]+\mathrm{T}[0]) \bmod 256$

nilai array $\mathrm{S}[0]=0$ dan $\mathrm{T}[0]=68$, sehingga :

$=(0+0+68) \bmod 256$

$\mathrm{j}=68$

swap (S[0], S[68]); i = 0 dan $\mathrm{j}=68$

artinya tukarkan isi array index ke-0 dengan isi array ke-68 dan begitu sebaliknya.

Iteasi $\mathrm{i}=1 ; \mathrm{j}=68$

$\mathrm{j}=(68+\mathrm{S}[1]+\mathrm{T}[1]) \bmod 256$

nilai $\mathrm{j}$ sebelumnya adalah 68 , array $\mathrm{S}[1]=1$ dan $\mathrm{T}[1]=105$, sehingga :

$=(68+1+105) \bmod 256$

$\mathrm{j}=174$

swap (S[1], S[174]); i = 1 dan $\mathrm{j}=175$

artinya tukarkan isi array S index ke-1 dengan isi array S ke-174 dan begitu sebaliknya. Proses ini dilakukan hingga iterasi ke 255 (seluruh nilai array S akan teracak). Proses ini memungkinkan nilai array tertukar lebih dari sekali. Hasil permutasi array S, ditunjukkan pada tabel 4 di bawah ini.

Tabel 4. Nilai Permutasi Array S

\begin{tabular}{cccccccccccccccc}
\hline 35 & 175 & 176 & 195 & 16 & 171 & 192 & 23 & 29 & 28 & 205 & 169 & 89 & 70 & 12 & 83 \\
204 & 47 & 255 & 19 & 123 & 85 & 101 & 206 & 165 & 162 & 36 & 184 & 74 & 201 & 42 & 127 \\
51 & 96 & 69 & 234 & 41 & 18 & 91 & 166 & 231 & 159 & 198 & 92 & 5 & 218 & 113 & 225 \\
7 & 136 & 79 & 216 & 34 & 191 & 124 & 132 & 137 & 156 & 39 & 187 & 9 & 141 & 105 & 24 \\
135 & 130 & 31 & 146 & 177 & 168 & 238 & 13 & 160 & 55 & 82 & 251 & 209 & 250 & 182 & 90 \\
221 & 151 & 88 & 199 & 40 & 131 & 147 & 21 & 80 & 22 & 66 & 110 & 220 & 246 & 58 & 121 \\
194 & 227 & 44 & 219 & 6 & 188 & 68 & 183 & 32 & 108 & 33 & 143 & 115 & 52 & 157 & 63 \\
172 & 11 & 129 & 240 & 50 & 134 & 253 & 104 & 8 & 4 & 14 & 247 & 232 & 243 & 45 & 186
\end{tabular}




\begin{tabular}{cccccccccccccccc}
144 & 94 & 99 & 189 & 155 & 142 & 193 & 122 & 30 & 150 & 98 & 28 & 116 & 133 & 72 & 139 \\
25 & 228 & 106 & 59 & 185 & 37 & 20 & 126 & 61 & 93 & 86 & 148 & 236 & 154 & 118 & 43 \\
213 & 102 & 111 & 38 & 212 & 100 & 203 & 164 & 109 & 26 & 140 & 233 & 190 & 1 & 174 & 71 \\
87 & 27 & 170 & 48 & 158 & 226 & 10 & 2 & 120 & 84 & 178 & 103 & 161 & 78 & 145 & 17 \\
114 & 202 & 254 & 81 & 214 & 153 & 46 & 241 & 173 & 200 & 249 & 60 & 207 & 224 & 235 & 217 \\
245 & 77 & 75 & 97 & 15 & 239 & 208 & 223 & 180 & 125 & 244 & 149 & 215 & 95 & 196 & 211 \\
53 & 248 & 163 & 49 & 28 & 252 & 67 & 76 & 54 & 119 & 237 & 62 & 229 & 197 & 112 & 242 \\
210 & 230 & 65 & 117 & 222 & 0 & 57 & 3 & 167 & 107 & 181 & 152 & 56 & 128 & 138 & 179 \\
\hline
\end{tabular}

2. Proses Pseudo Random Generation Algorithm (PRGA)

Proses ini merupakan proses yang dilakukan untuk membangkitkan key stream (aliran kunci) yang digunakan pada proses enkripsi dan dekripsi SMS berdasarkan beaufort cipher. Jumlah kunci yang dibangkitkan sesuai dengan jumlah karakter teks SMS yang disandikan. Contoh kasus pada penelitian ini memiliki jumlah karakter SMS adalah 10, sehingga akan dibangkitkan 10 kunci yang baru. Pembangkitan kunci yang acak menggunakan nilai-nilai array $\mathrm{S}$ hasil permutasi.

Bila iterasi $\mathrm{i}=0 ; \mathrm{j}=0$, maka :

$\mathrm{i}=(0+1) \bmod 256$

$\mathrm{i}=1$

$\mathrm{j}=(0+\mathrm{S}[1]) \bmod 256$

$=(0+175) \bmod 256$

$\mathrm{j}=175$

swap (S[1], S[175])

$\mathrm{t}=(\mathrm{S}[1]+\mathrm{S}[175]) \bmod 256$

$=(175+71) \bmod 256$, nilai array S pada index 175 adalah 71

$=246 \bmod 256$

$\mathrm{t}=246$, sehingga didapatkan :

Kunci [1] = S[246]

Kunci [1] $=57$, nilai array S pada index 246 adalah 57

Artinya kunci yang digunakan untuk mengenkripsi karakter pertama adalah nilai desimal 57.

Bila iterasi $\mathrm{i}=1 ; \mathrm{j}=175$ (nilai $\mathrm{j}$ iterasi sebelumnya), maka :

$\mathrm{i}=(1+1) \bmod 256$

$\mathrm{i}=2$

$\mathrm{j}=(175+\mathrm{S}[2]) \bmod 256$

$=(175+176) \bmod 256$

$\mathrm{j}=95$

swap (S[2], S[95])

$\mathrm{t}=(\mathrm{S}[2]+\mathrm{S}[95]) \bmod 256$

$=(176+121) \bmod 256$, nilai array S pada index 95 adalah 121

$=41 \bmod 256$

$\mathrm{t}=41$, sehingga didapatkan :

Kunci [2] = S[41]

Kunci [2] = 159, nilai array S pada index 41 adalah 159 
Artinya kunci yang digunakan untuk menyandikan karakter SMS (huruf ke dua) adalah nilai desimal 159 .

Proses ini dilakukan hingga iterasi ke 10 (jumlah karakter SMS), sehingga nilai bilangan kunci yang dibangkitkan secara acak adalah 57, 159, 41, 94, 42, 189, 78, 163, 200, 201 (terlihat bahwa bukan lagi nilai-nilai kunci awal).

3. Proses Enkripsi dan Dekripsi

Proses enkripsi dilakukan berdasarkan formula enkripsi beuafort cipher (persamaan 3).

$$
\begin{aligned}
\mathrm{C}_{1} & =\left(\mathrm{K}_{1}-\mathrm{M}_{1}\right) \bmod 256 \\
& =(57-\mathrm{H}) \bmod 256 \\
& =(57-72) \bmod 256 \\
& =241(\mathrm{char} \tilde{\mathrm{n}}) \\
\mathrm{C}_{2} & =\left(\mathrm{K}_{2}-\mathrm{M}_{2}\right) \bmod 256 \\
& =(159-\mathrm{a}) \bmod 256 \\
& =(159-97) \bmod 256 \\
& =62(\mathrm{char}>)
\end{aligned}
$$

Cipher lainnya dicari dengan cara yang sama, sehingga sandi SMS Hai Mia... adalah $\tilde{\mathbf{n}}>\hat{A}>\hat{\mathbf{Y}}-$ Ÿòòò

Proses dekripsi oleh penerima SMS yang diawali oleh proses pembangkitan kunci berdasarkan algoritma RC4 (proses KSA dan PRGA), kemudian melakukan proses dekripsi berdasarkan persamaan 4.

$$
\begin{aligned}
\mathrm{P}_{1} & =\left(\mathrm{K}_{1}-\mathrm{C}_{1}\right) \bmod 256 \\
& =(57-\tilde{\mathrm{n}}) \bmod 256 \\
& =(57-241) \bmod 256 \\
& =72(\text { char } \mathrm{H}) \\
\mathrm{P}_{2} & =\left(\mathrm{K}_{2}-\mathrm{C}_{2}\right) \bmod 256 \\
& =(159->) \bmod 256 \\
& =(57-62) \bmod 256 \\
& =97(\text { char a })
\end{aligned}
$$

demikian seterusnya, hingga dihasilkan plaintext SMS adalah Hai Mia...

\section{KESIMPULAN}

Berdasarkan uraian analisa dan pembahasan, maka disimpulkan beberapa hal sebagai berikut :

a. Optimaliasi pembangkitan kunci sejumlah plaintext berdasarkan proses KSA dan PRGA dari algoritma RC4 terhadap beaufort cipher sangat efektif, karena pengguna dapat menggunakan jumlah karakter kunci yang jauh lebih kecil dibandingkan jumlah plaintext sehingga mudah mengingatnya.

b. Kunci yang dihasilkan cukup acak dan bahkan menghasilkan karakter-karakter kunci yang baru sehingga prinsip diffusion pada kunci terwujudkan.

c. Pengamanan SMS berdasarkan beaufort cipher yang telah dioptimalisasikan cukup baik yang dapat dibuktikan dengan tidak terlihatnya karakteristik dan pola plain SMS dengan cipher SMS yang dihasilkan sehingga hal ini dapat mengelabui dan mempersulit para penyerang. 


\section{DAFTAR PUSTAKA}

[1] N. Widyastuti, "Pengembangan Metode Beaufort Cipher Menggunakan Pembangkit Kunci Chaos," J. Teknol., vol. 7, no. 1, pp. 73-82, 2014.

[2] E. Setyaningsih, "Penyandian Citra Menggunakan Metode Playfair Cipher", J. Teknol., vol. 2, no. 2, pp. 213-219, 2009.

[3] T. Zebua and E. Ndruru, "PENGAMANAN CITRA DIGITAL BERDASARKAN MODIFIKASI ALGORITMA RC4," J. Teknol. Infomasi dan Ilmu Komput., vol. 4, no. 4, pp. 275-282, 2017.

[4] H. Agung and Budiman. "Implementasi Affine Chiper dan RC4 Pada Enkripsi File Tunggal," Prosiding SNATIF, pp. 243-250, 2015

[5] S. Subhan, S. Amini, and P. F. Ariyani, "Implementasi Pengamanan Data Enkripsi Sms Dengan Algoritma RC4 Berbasis Android," in Seminar Nasional Inovasi Dan Aplikasi Teknologi Di Industri 2017 ITN Malang, 2017, pp. 1-6.

[6] F. Purwaningsih and M. Badrul, "Penerapan algoritma huffman untuk aplikasi pengamanan sms berbasis android," J. PROSISKO, vol. 4, no. 2, pp. 60-66, 2017.

[7] W. P. Atmojo, R. R. Isnanto, and R. Kridalukmana, "Implementasi Aplikasi Kriptografi Pada Layanan Pesan Singkat (SMS) Menggunakan Algoritma RC6 Berbasis Android," J. Teknol. dan Sist. Komput., vol. 4, no. 3, p. 450, 2016.

[8] E. Setyaningsih, Kriptografi \& Implementasinya Menggunakan Matlab, Yogyakarta:Andi, 2015.

[9] T. Zebua, "ANALISA DAN IMPLEMENTASI ALGORITMA TRIANGLE CHAIN PADA PENYANDIAN RECORD DATABASE," Pelita Inform. Budi Darma, vol. 3, no. 2, pp. 37-49, 2013.

[10] R. Sadikin, Kriptografi Untuk Keamanan Jaringan dan Implementasinya dalam Bahasa Java, Yogyakarta: Andi, 2012.

[11] Wikipedia, "Beaufort Cipher," [online]. Available: https://en.wikipedia.org/ wiki/Beaufort_cipher, 2017 [Accessed 30 Januari 2018]. 